\title{
Article \\ Diversity of Leaf Cuticular Transpiration and Growth Traits in Field-Grown Wheat and Aegilops Genetic Resources
}

\author{
Kristína Gašparovič ${ }^{1}$, Marek Živčák ${ }^{1, *} \mathbb{0}$, Marián Brestič ${ }^{1}\left(\mathbb{D}\right.$ and Pavol Hauptvogel ${ }^{2}$ \\ 1 Department of Plant Physiology, Faculty of Agrobiology and Food Resources, Slovak University of \\ Agriculture, 94901 Nitra, Slovakia; kristina.gasparovic@uniag.sk (K.G.); marian.brestic@uniag.sk (M.B.) \\ 2 National Agricultural and Food Centre, Research Institute of Plant Production, 92168 Piešt'any, Slovakia; \\ pavol.hauptvogel@nppc.sk \\ * Correspondence: marek.zivcak@uniag.sk
}

Citation: Gašparovič, K.; Živčák, M.; Brestič, M.; Hauptvogel, P. Diversity of Leaf Cuticular Transpiration and Growth Traits in Field-Grown Wheat and Aegilops Genetic Resources. Agronomy 2021, 11, 522. https:// doi.org/10.3390/agronomy11030522

Academic Editor: J. Stephen C Smith

Received: 31 January 2021

Accepted: 7 March 2021

Published: 11 March 2021

Publisher's Note: MDPI stays neutral with regard to jurisdictional claims in published maps and institutional affiliations.

Copyright: (c) 2021 by the authors. Licensee MDPI, Basel, Switzerland. This article is an open access article distributed under the terms and conditions of the Creative Commons Attribution (CC BY) license (https:// creativecommons.org/licenses/by/ $4.0 /)$.

\begin{abstract}
Plants are subjected to unregulated water loss from their surface by cuticular transpiration. Therefore, specific morphophysiological changes may occur during leaf development to eliminate water loss. This study aimed to examine the cuticular transpiration of 23 winter wheat genotypes and their wild-growing predecessors of the genus Aegilops, which were divided into three groups to demonstrate their diversity. The genotypes were sown in autumn and grown in regular field trials at the Research Institute of Plant Production in Piešt'any, Slovakia. Cuticular transpiration and growth parameters were analyzed in the postanthesis growth stage. Gravimetric measurement of residual water loss was performed on detached leaves with a precisely measured leaf area. The lowest nonproductive transpiration values were observed in modern wheat genotypes, while higher cuticular transpiration was observed in a group of landraces. Aegilops species generally showed the highest cuticular transpiration with increased water loss, but the total water loss per plot was low due to the low leaf area of the wild wheat relatives. Some of the growth parameters showed a good correlation with cuticular transpiration (e.g., dry mass per plant), but direct relationships between leaf traits and cuticular transpiration were not observed. This study identified a high diversity in cuticular resistance to water loss in wheat and Aegilops accessions of different origins. The potential of identifying and exploiting genetic resources with favorable cuticular transpiration in crop breeding is discussed.
\end{abstract}

Keywords: cuticular transpiration; winter wheat; Aegilops genotypes; morpho-physiological traits

\section{Introduction}

The plant cuticle plays a crucial role in the survival of terrestrial plants [1,2]. Representing a dynamic and selective barrier between the plant and the atmosphere, it delays the onset of cellular dehydration stress under drought and is therefore considered an essential component of protection from drought [3-6]. Plants have two major water loss pathways: under normal conditions, stomatal transpiration accounts for most of the water loss of plants $[7,8]$. Under limited water availability, the extent of cuticular transpiration of the water in the plant and water acquisition from the soil significantly impacts plant fitness and survival $[8,9]$.

Cuticular (or residual) transpiration represents the main method of water loss during the night under optimal conditions and at noon under drought conditions, when the stomata are closed [10]. Cuticle thickness, ultrastructure, and chemical composition can vary dramatically in a species-, organ- and tissue-specific manner $[2,11]$. Thus, as they develop their leaves, plants can resort to specific morphological alterations to regulate their water losses, such as changes in the palisade parenchyma thickness [12] or the epidermis and cuticle water tightness [13], the latter being essential to control water losses, especially during drought periods, through cuticular transpiration [14,15]. 
Abiotic stress factors, particularly water deficits, limit crop production, accounting for more than $50 \%$ of yield losses worldwide [16-18]. Drought is generally accepted as the most widespread abiotic stress experienced by crops and it is becoming an increasingly severe problem in many regions around the world [10].

The wheat tribe (Poaceae: Triticeae) includes approximately 450 diploid and polyploid species that are distributed in a wide range of ecological habitats over temperate, subtropical, and tropical alpine regions [19,20], and these species are affected annually by the adverse effects of environmental stress [21]. Wheat is an important food crop worldwide, grown across millions of hectares [22], supplying $20 \%$ of calories and protein to the human diet [23].

Modern highly productive cultivars of hexaploid crop wheat (Triticum aestivum) were developed from wild diploid and tetraploid wheat species and two species of the genus Aegilops [24]; therefore, the Aegilops genus is closely related to Triticum [25,26]. Wild relatives of common wheat are an ideal source of genes related to biotic and abiotic stress resistance and have a long history in wheat breeding, predominantly for improving resistance to heat and drought [26,27], salinity [28], high temperature [29], and cold [30,31]. Physiological and morphological acclimation traits tend to depend on the climate in the native habitat of the plant species [27,32]. Aegilops species are indigenous to the Mediterranean region and are obliged to develop various acclimation strategies to survive a shorter or longer period of drought [26].

Similarly, wheat genotypes of different origins have been evaluated to assess stress responses and mechanisms of stress tolerance [33-35]. Although multiple studies have focused on different traits associated with drought tolerance in wheat, including cuticular transpiration, studies providing information on variability in a diverse collection of wheat genetic responses are rather scarce. In particular, information comparing wheat and Aegilops genetic resources is almost completely absent. Therefore, our study aimed to fill this gap and examine cuticular transpiration in a diverse collection of wheat and Aegilops genetic resources to demonstrate their diversity and provide information useful for breeders.

\section{Materials and Methods}

\subsection{Biological Material}

The parameters were monitored in 23 genotypes of winter wheat (Triticum aestivum L.) and its wild-growing relatives of the genus Aegilops L. From the genus Triticum L., there were ten modern genotypes of various provenances: Biscay (GER), GK Forrás (HUN), Piopio 4 (MEX), Astella (SVK), Verna (ITA), Steklovidnaja 24 (KAZ), Mottin (ITA), Pehlivan (TUR), Shaan 8007-7 (CHN) and Shark 4 (MEX), and five landrace genotypes: Diosecká 85-6, Vígl'ašská červenoklasá, Šamorínska, Vrakúnska, and Radošínska Norma. From secondary wild-type ancestors, changes were observed in five Armenian genotypes: Aegilops biuncialis (ARMEN06-53), Ae. columnaris (ARMEN06-04), Ae. cylindrica (ARMEN06-02), Ae. tauschii (ARMEN06-40), Ae. triuncialis (ARMEN06-06); 2 Slovak genotypes: Ae. cylindrica (SVKBUR05-13), Ae. cylindrica (SVKHUN06-48) and one Italian genotype: Ae. geniculata (ITASIC05-01).

\subsection{Field Vegetation Experiments}

Plants of both species were grown on experimental plots in the GenBank of National Agricultural and Food Centre, Research Institute of Plant Production in Piešt'any, Slovakia. The soil type was degraded chernozem on loess, with a topsoil depth of $0.4 \mathrm{~m}$ and a humus content of $1.8-2.0 \%$, with medium $\mathrm{P}$ and $\mathrm{K}$ stocks and neutral to weakly acidic soil reactions. The precrop was field peas. Plants were grown on plots of $2.5 \mathrm{~m}^{2}$ (Triticum L.) and $3 \mathrm{~m}^{2}$ (Aegilops L.). Both species were fertilized with $330 \mathrm{~kg} \mathrm{ha}^{-1}$ NPK (15-15-15) in the autumn. Wheat was fertilized with $137 \mathrm{~kg} \mathrm{ha}^{-1}$ Amofos fertilizer $\left(12 \% \mathrm{~N}, 52 \% \mathrm{P}_{2} \mathrm{O}_{5}\right)$ and $100 \mathrm{~kg} \mathrm{ha}^{-1} \mathrm{DS} 60 \% \mathrm{~K}_{2} \mathrm{O}$. Aegilops was fertilized with $50 \mathrm{~kg} \mathrm{ha}^{-1}$ Amofos fertilizer and $90 \mathrm{~kg} \mathrm{ha}^{-1}$ DS $60 \% \mathrm{~K}_{2} \mathrm{O}$. Spring fertilization was applied at a dose of $110 \mathrm{~kg} \mathrm{ha}^{-1}$ ammonium nitrate $(27 \% \mathrm{~N})$. Autumn and spring herbicide treatments were also applied. 
In the observed vegetation period from May to June, the average air temperature was $17.84^{\circ} \mathrm{C}$, the average soil temperature was $17.56^{\circ} \mathrm{C}$ with an average monthly rainfall of $43.1 \mathrm{~mm}$, soil moisture of $37.7 \%$, and air humidity of $55.8 \%$.

\subsection{Analyses of Growth Parameters}

All analyses of the parameters were performed after anthesis when all genotypes had fully developed flag leaves and the plants had reached their maximum leaf area. The analyses of growth and leaf traits were performed in all genotypes.

Plants from a fixed area per plot were harvested. After identifying individual plants, they were subdivided into a leaf fraction (leaf DM) and a stem fraction (stem DM). Leaf area was determined using a standard scanner, and subsequent image analysis was performed using ImageJ software (National Institute of Health, Bethesda, MD, USA). Total aboveground dry matter and leaf dry matter were standardized to $\mathrm{m}^{2}$. The values of the following parameters were calculated and further statistically processed: plant leaf area (PLA), flag leaf area (FLA), leaf area index (LAI), dry mass per leaf area (LMA), and dry mass per plot (DMP).

\subsection{Determination of Cuticular Transpiration}

Cuticular transpiration was realized in parallel in the leaves of all genotypes by a simple gravimetric method analyzing the water loss of detached leaves [9]. The intact detached leaves were harvested in the field, scanned, and saturated with water in the darkness for $3 \mathrm{~h}$ before the start of the transpiration measurement, thus ensuring that the stomata were closed. Then, the leaves were transported into a dark chamber (with a weak green light enabling operations in the chamber, but low enough to have a negligible effect on plant stomata) with a stable temperature $\left(25^{\circ} \mathrm{C}\right)$ and low air humidity (app. 30\%). The leaves were placed on filtration paper, and leaf drying curves were measured gravimetrically at regular intervals $(30 \mathrm{~min}$ ) for $\sim 3 \mathrm{~h}$. The water loss was recalculated per leaf area and then calculated for all time intervals in $\mathrm{g} \mathrm{m}^{-2} \mathrm{~h}^{-1}$. The curves had typical exponential decay trends (Supplementary Materials Figure S1). When the water loss in individual leaves became steady (showing a linear trend), the values of three subsequent intervals were averaged, representing an estimate of cuticular transpiration (in $\mathrm{g} \mathrm{m}^{-2} \mathrm{~h}^{-1}$ ). The leaf area was determined by scanning and subsequent image analysis using ImageJ 1.53 software (National Institute of Health, Bethesda, MD, USA).

To obtain a rough estimate of total water loss due to cuticular transpiration, the water loss per $\mathrm{m}^{2}$ of the canopy was calculated as a product of LAI and cuticular transpiration. Analogically, the water loss per dry mass unit was calculated as a ratio of water loss per $\mathrm{m}^{2}$ of the canopy and dry mass per $\mathrm{m}^{2}$ of the canopy.

\subsection{Statistical Analyses}

Statistical analysis was performed using analysis of variance (ANOVA) followed by the post hoc Tukey HSD test using Statistica version 9.0 software (Statsoft Inc., Tulsa, OK, USA). The data presented in the tables represent mean values \pm standard error (SE). The hierarchical cluster analysis to the parameters was also performed, using Euclidean coefficient and Ward's method.

\section{Results}

The leaf and growth traits were evaluated in 23 winter Triticeae (wheat and Aegilops) genotypes. Differences among the genotypes were highly significant for all traits $(p<0.05)$; therefore, the specific results of the ANOVA are not displayed here, and we focused mainly on the comparisons of individual genotypes and groups of genotypes.

To examine cuticular transpiration (CT), water loss curves were recorded for individual leaves. The results (Table 1$)$ indicate significant differences $(p<0.05)$ among the groups but also within all three groups of Triticeae. The lowest cuticular transpiration was observed in the group of modern wheat genotypes (Biscay, Piopio-4, and Mottin), in which we found 
almost 50\% lower cuticular transpiration compared to the average value found in all genotypes ( 11.70 to $12.93 \mathrm{~g} \mathrm{~m}^{2} \mathrm{~h}^{-1}$ ). The five wheat genotypes of the landrace group analyzed for cuticular transpiration and water loss showed relatively low variability, and the values were close to the average. The highest cuticular transpiration was found in Aegilops. The average of 10 modern genotypes $\left(16.54 \mathrm{~g} \mathrm{~m}^{2} \mathrm{~h}^{-1}\right)$ was similar to the value of the Aegilops genotype with the lowest cuticular transpiration (SVKBUR05-13; $16.63 \mathrm{~g} \mathrm{~m}^{2} \mathrm{~h}^{-1}$ ). However, most of the genotypes of this wild species had much higher cuticular transpiration, and two of the genotypes, ARMEN06-53 and ARMEN 06-06, showed water loss two times above the average and almost four times higher than that of the best modern wheat genotypes (40.42 and $46.13 \mathrm{~g} \mathrm{~m}^{2} \mathrm{~h}^{-1}$ ). It must be pointed out that the genotypes with the highest cuticular transpiration were found in Ae. biuncialis and Ae. triuncialis, which are much less used for breeding purposes than the other Aegilops species analyzed in this study. Although the values found in wild species were significantly higher than those in the best modern wheat species, there was sufficient variability found in this trait, and genotypes with cuticular transpiration below the average could be identified.

Comparison of the main leaf traits also identified significant differences between and within the groups of genotypes. The dry mass per leaf area (MLA), which mostly represents the differences in leaf thickness, identified the highest values in a group of modern genotypes, mostly values above $40 \mathrm{~g} \mathrm{~m}^{-2}$ (with one exception). In the group of landraces, about half of the genotypes had values below $40 \mathrm{~g} \mathrm{~m}^{-2}$, but there were also genotypes with relatively thick leaves. The lowest average MLA value was found in Aegilops, in which most of the genotypes had thin leaves. On the other hand, some accessions with thinner leaves were also found in modern wheat genotypes and, especially, in a landrace group. Moreover, in two accessions of the wild wheat relative, ARMEN06-04 (Ae. columnaris) and ITASIC05-01 (Ae. geniculata), we found a leaf thickness comparable to most modern genotypes.

The flag leaf area was the trait in which we identified a much higher difference between wheat and wild relative species, as the Aegilops had, on average, more than three times smaller leaves than wheat. There was no accession of Aegilops with leaves close to the average of the wheat. We also found differences between the modern varieties of wheat and the landraces, where more genotypes with large leaves were found in the modern genotypes, but we found one Mexican genotype with small leaves. In landraces, most genotypes were below the average of wheat accessions, but there was also a genotype with a large flag leaf (Vrakunska).

The trends observed in the flag leaf area were similar to those of total plant leaf area and LAI (Table 2), especially for the low leaf area found in Aegilops and a higher average leaf area found in modern genotypes compared to landraces.

The plants differed significantly in growth (Table 2), with the landraces demonstrating the highest biomass production per plot $\left(1375 \mathrm{~g} \mathrm{~m}^{-2}\right)$. This was expected, considering the much lower height of modern semidwarf genotypes than landraces, resulting in differences in straw production. The highest biomass was observed in Steklovidnaja-24, the genotype originating from central Asia. Aegilops genotypes produced significantly smaller biomass per ground area $\left(296 \mathrm{~g} \mathrm{~m}^{-2}\right)$. In this group, we observed the highest variability among the genotypes, where the best genotype, SVKHUN06-48 (Ae. cylindrica), produced more than two times higher biomass than ARMEN06-06 (Ae. triuncialis).

In general, analyses of the leaf and growth traits showed that the Ae. cylindrica genotypes were more robust than the rest of the genotypes. On the other hand, this species did not show more favorable leaf traits than the other Aegilops species, so we cannot identify a single genotype or species with the most favorable leaf and growth traits. 
Table 1. Leaf traits analyzed in three groups of Triticeae genotypes \#.

\begin{tabular}{|c|c|c|c|c|}
\hline Genotype & $\begin{array}{c}\text { Cuticular } \\
\text { Transpiration (CT) } \\
\left(\mathrm{g} \mathrm{m}^{-2} \mathrm{~h}^{-1}\right)\end{array}$ & $\begin{array}{c}\text { Dry Mass Per } \\
\text { Leaf Area (MLA) } \\
\left(\mathrm{g} \mathrm{m}^{-2}\right)\end{array}$ & $\begin{array}{c}\text { Flag Leaf Area } \\
\text { (FLA) } \\
\left(\mathrm{cm}^{2}\right)\end{array}$ & $\begin{array}{c}\text { Plant Leaf Area } \\
\text { (PLA) } \\
\left(\mathrm{cm}^{2}\right)\end{array}$ \\
\hline \multicolumn{5}{|c|}{ Group-modern varieties } \\
\hline Biscay & $11.7 \pm 0.7^{\mathrm{a}}$ & $44.3 \pm 2.0^{\mathrm{efg}}$ & $28.6 \pm 2.5^{h}$ & $278 \pm 18^{\text {efgh }}$ \\
\hline GK Forrás & $20.1 \pm 1.2^{c}$ & $39.6 \pm 1.3^{\mathrm{ab}}$ & $22.4 \pm 1.1^{\mathrm{f}}$ & $346 \pm 20$ ghi \\
\hline Piopio-4 & $12.9 \pm 0.7^{\mathrm{ab}}$ & $43.7 \pm 0.7$ ef & $18.0 \pm 0.6$ de & $307 \pm 23$ fghi \\
\hline Astella & $16.6 \pm 0.4^{\mathrm{abc}}$ & $49.2 \pm 0.8$ gh & $29.0 \pm 2.1^{h}$ & $279 \pm 12$ efgh \\
\hline Verna & $16.9 \pm 1.1^{\mathrm{abc}}$ & $42.3 \pm 1.0$ ef & $26.9 \pm 1.5 \mathrm{gh}$ & $517 \pm 30^{j}$ \\
\hline Steklovidnaja-24 & $19.5 \pm 2.0^{c}$ & $44.3 \pm 1.9$ efg & $30.8 \pm 2.2 \mathrm{hi}$ & $251 \pm 11^{\text {ef }}$ \\
\hline Mottin & $12.9 \pm 0.9^{\mathrm{ab}}$ & $40.8 \pm 1.2^{\text {cde }}$ & $24.3 \pm 2.3^{\mathrm{fg}}$ & $489 \pm 14^{j}$ \\
\hline Pehlivan & $18.1 \pm 0.7^{b c}$ & $40.0 \pm 1.4$ bcde & $34.3 \pm 1.9^{\mathrm{i}}$ & $364 \pm 36^{\mathrm{hi}}$ \\
\hline Shaan $8007-7$ & $16.4 \pm 0.6^{\mathrm{abc}}$ & $52.3 \pm 1.5^{\mathrm{h}}$ & $22.6 \pm 1.0^{\mathrm{f}}$ & $269 \pm 18^{\text {efgh }}$ \\
\hline Shark-4 & $20.1 \pm 1.8^{c}$ & $46.7 \pm 0.6^{\mathrm{fg}}$ & $16.2 \pm 1.2^{\mathrm{d}}$ & $383 \pm 4^{\mathrm{i}}$ \\
\hline Average (modern varieties) & 16.5 & 44.3 & 25.3 & 348 \\
\hline \multicolumn{5}{|c|}{ Group-landraces } \\
\hline Diosecká 85-6 & $16.6 \pm 0.8^{a b c}$ & $42.7 \pm 2.9^{\text {ef }}$ & $21.6 \pm 0.6^{\text {ef }}$ & $333 \pm 32$ fghi \\
\hline Vigl'ašská červenoklasá & $18.0 \pm 3.2 \mathrm{bc}$ & $32.1 \pm 1.4^{\mathrm{a}}$ & $21.8 \pm 1.8$ ef & $349 \pm 54$ ghi \\
\hline Šamorínska & $21.4 \pm 1.4^{\mathrm{c}}$ & $41.7 \pm 1.9$ def & $20.8 \pm 2.1$ ef & $212 \pm 36^{\mathrm{de}}$ \\
\hline Vrakúnska & $17.6 \pm 0.8^{b c}$ & $38.8 \pm 1.8$ bcde & $27.2 \pm 0.3 \mathrm{gh}$ & $282 \pm 19$ efgh \\
\hline Radošínska Norma & $21.4 \pm 0.5^{c}$ & $41.5 \pm 1.4^{\text {def }}$ & $22.8 \pm 1.1^{\mathrm{f}}$ & $265 \pm 12$ efgh \\
\hline Average (landraces) & 19.0 & 39.3 & 22.8 & 288 \\
\hline \multicolumn{5}{|c|}{ Group-Aegilops } \\
\hline ARMEN06-53 (Ae. biuncialis) & $40.4 \pm 2.8^{\mathrm{e}}$ & $39.1 \pm 1.5^{\text {bcde }}$ & $3.8 \pm 0.1^{\mathrm{a}}$ & $48 \pm 4^{\mathrm{a}}$ \\
\hline ARMEN06-04 (Ae. columnaris) & $33.8 \pm 1.7^{\mathrm{d}}$ & $44.1 \pm 1.7 \mathrm{efg}$ & $14.2 \pm 0.1 \mathrm{~cd}$ & $90 \pm 28 \mathrm{abc}$ \\
\hline ARMEN06-02 (Ae. cylindrica) & $28.9 \pm 2.9^{d}$ & $34.8 \pm 1.1^{\mathrm{ab}}$ & $10.5 \pm 0.6^{\mathrm{bc}}$ & $85 \pm 7$ abc \\
\hline ITASIC05-01 (Ae. geniculata) & $22.3 \pm 1.6^{c}$ & $43.8 \pm 1.6^{\text {ef }}$ & $2.6 \pm 0.3^{\mathrm{a}}$ & $40 \pm 0.3^{\mathrm{a}}$ \\
\hline ARMEN06-40 (Ae. tauschii) & $18.4 \pm 2.5 \mathrm{bc}$ & $39.1 \pm 0.9$ bcde & $7.7 \pm 0.3^{b}$ & $157 \pm 38^{b c d}$ \\
\hline ARMEN06-06 (Ae. triuncialis) & $46.1 \pm 2.7^{\mathrm{f}}$ & $36.6 \pm 1.1^{\mathrm{abcd}}$ & $2.6 \pm 0.1^{\mathrm{a}}$ & $82 \pm 11^{\mathrm{abc}}$ \\
\hline SVKBUR05-13 (Ae. cylindrica) & $16.6 \pm 1.5^{\mathrm{abc}}$ & $32.3 \pm 2.8^{a}$ & $9.8 \pm 0.4^{b}$ & $136 \pm 32 \mathrm{bcd}$ \\
\hline SVKHUN06-48 (Ae. cylindrica) & $20.7 \pm 1.1^{\mathrm{c}}$ & $35.8 \pm 1.7 \mathrm{abc}$ & $10.5 \pm 0.7^{b}$ & $167 \pm 35^{\mathrm{cd}}$ \\
\hline Average (Aegilops) & 28.4 & 38.2 & 7.7 & 101 \\
\hline
\end{tabular}

${ }^{\#}$ Average values $\pm \mathrm{SE}$; different letters indicate statistically significant differences indicated by Duncan's test at $p<0.05$.

We also converted the water loss by cuticular transpiration per leaf area (cuticular transpiration values) into water loss per canopy ground area and dry mass unit (Table 2). Although this calculation is not entirely correct (considering possible differences in cuticular transpiration of leaves in different positions) and provides only a very rough estimate, this calculation illustrates and compares the importance of cuticular transpiration for water loss at the canopy scale. Our results indicate that the highest water loss by cuticular transpiration from leaves was found in modern genotypes, whereas the lowest water loss was found in Aegilops. On the other hand, the modern wheat varieties with the lowest cuticular transpiration had quite favorable values, comparable to the average Aegilops.

The recalculation of water loss per dry mass unit enables a rough comparison from the perspective of water use efficiency. The results indicate the most favorable values in the group of landraces, followed by modern wheat genotypes. The loss of water by cuticular transpiration per produced biomass in Aegilops was very high, especially in some accessions.

An important question was whether there are some relationships between the leaf and growth traits and cuticular transpiration. This is especially relevant for the leaf traits (leaf thickness, leaf area) for which we can expect some direct influence. Therefore, we also conducted correlation analyses in which we tested correlations among all of the traits assessed (Table 3). 
Table 2. Growth traits and estimates of water loss characteristics in three groups of Triticeae\#.

\begin{tabular}{|c|c|c|c|c|}
\hline Genotype & $\begin{array}{c}\text { Dry Mass Per } \\
\text { Ground Area (DM) } \\
\left(\mathrm{g} \mathrm{m}^{-2}\right)\end{array}$ & $\begin{array}{c}\text { LAI } \\
\left(\mathrm{m}^{2} \mathrm{~m}^{-2}\right)\end{array}$ & $\begin{array}{l}\text { Water Loss by CT } \\
\text { Per Ground Area } \\
\qquad\left(\mathrm{g} \mathrm{m}^{-2}\right)\end{array}$ & $\begin{array}{c}\text { Water Loss by CT } \\
\text { Per Dry Mass Unit } \\
\left(\mathrm{mg} \mathrm{g}^{-1}\right)\end{array}$ \\
\hline \multicolumn{5}{|c|}{ Group-modern varieties } \\
\hline Biscay & $978 \pm 67$ & $5.0 \pm 0.3^{\text {efgh }}$ & $58.6 \pm 5.2^{\text {cdef }}$ & $92.0 \pm 8.1^{\mathrm{a}}$ \\
\hline GK Forrás & $795 \pm 45$ & $6.2 \pm 0.4$ ghi & $125.2 \pm 10.4^{\mathrm{kl}}$ & $191.7 \pm 20.2^{g}$ \\
\hline Piopio-4 & $994 \pm 77$ & $5.5 \pm 0.4$ fghi & $71.3 \pm 6.8^{\text {efgh }}$ & $110.2 \pm 10.5^{\text {bcde }}$ \\
\hline Astella & $1280 \pm 53$ & $5.0 \pm 0.2 \mathrm{efgh}$ & $83.7 \pm 4.1$ ghi & $100.4 \pm 4.9^{\mathrm{a}}$ \\
\hline Verna & $1553 \pm 90$ & $9.3 \pm 0.5^{j}$ & $157.8 \pm 14.0^{\mathrm{m}}$ & $156.0 \pm 13.8$ ef \\
\hline Steklovidnaja-24 & $2059 \pm 98$ & $4.5 \pm 0.2$ ef & $88.1 \pm 10.0^{\mathrm{hi}}$ & $65.7 \pm 7.5^{\mathrm{a}}$ \\
\hline Mottin & $1117 \pm 20$ & $8.8 \pm 0.2^{j}$ & $113.7 \pm 8.5^{\mathrm{jk}}$ & $156.5 \pm 11.7 \mathrm{bcd}$ \\
\hline Pehlivan & $1152 \pm 111$ & $6.6 \pm 0.6^{\mathrm{hi}}$ & $118.5 \pm 12.4^{\mathrm{jkl}}$ & $158.0 \pm 16.5^{\text {def }}$ \\
\hline Shaan $8007-7$ & $1032 \pm 92$ & $4.8 \pm 0.4$ efg & $79.7 \pm 7.8$ fghi & $118.7 \pm 11.5^{\mathrm{abc}}$ \\
\hline Shark-4 & $1358 \pm 16$ & $6.9 \pm 0.1^{\mathrm{i}}$ & $138.5 \pm 12.4^{\mathrm{lm}}$ & $156.6 \pm 14.0$ def \\
\hline Average-modern varieties & 1232 & 6.27 & 103.5 & 135.6 \\
\hline \multicolumn{5}{|c|}{ Group-landraces } \\
\hline Diosecká 85-6 & $1579 \pm 137$ & $6.0 \pm 0.5$ fghi & $99.7 \pm 9.9^{\mathrm{ij}}$ & $97.0 \pm 9.7^{\mathrm{a}}$ \\
\hline Vigl'ašská červenoklasá & $1044 \pm 186$ & $6.3 \pm 1.1$ ghi & $67.1 \pm 7.8^{\text {defgh }}$ & $98.8 \pm 11.5^{\mathrm{a}}$ \\
\hline Šamorínska & $1424 \pm 256$ & $3.8 \pm 0.7 \mathrm{de}$ & $81.8 \pm 5.4$ fghi & $88.2 \pm 5.8^{a}$ \\
\hline Vrakúnska & $1311 \pm 100$ & $5.1 \pm 0.4^{\text {efgh }}$ & $89.5 \pm 8.0 \mathrm{hi}$ & $104.9 \pm 9.4^{\mathrm{a}}$ \\
\hline Radošínska Norma & $1519 \pm 76$ & $4.8 \pm 0.2$ efg & 102. $\pm 5.5^{\mathrm{ijk}}$ & $103.6 \pm 5.6^{\mathrm{ab}}$ \\
\hline Average-landraces & 1375 & 5.2 & 88.1 & 98.5 \\
\hline \multicolumn{5}{|c|}{ Group-Aegilops } \\
\hline ARMEN06-53 (Ae. biuncialis) & $193 \pm 18$ & $0.86 \pm 0.08^{a}$ & $34.1 \pm 2.8^{\mathrm{ab}}$ & $271.6 \pm 22.1^{\mathrm{gh}}$ \\
\hline ARMEN06-04 (Ae. columnaris) & $285 \pm 90$ & $1.63 \pm 0.52 \mathrm{abc}$ & $55.1 \pm 2.8$ bcde & $297.6 \pm 15.2^{h}$ \\
\hline ARMEN06-02 (Ae. cylindrica) & $389 \pm 31$ & $1.52 \pm 0.12 \mathrm{abc}$ & $44.0 \pm 4.3^{\mathrm{bcd}}$ & $174.0 \pm 17.2^{\mathrm{f}}$ \\
\hline ITASIC05-01 (Ae. geniculata) & $236 \pm 24$ & $0.72 \pm 0.07^{\mathrm{a}}$ & $16.2 \pm 2.1^{a}$ & $105.3 \pm 13.9^{a}$ \\
\hline ARMEN06-40 (Ae. tauschii) & $322 \pm 83$ & $2.83 \pm 0.72^{b c d}$ & $52.0 \pm 7.1$ bcde & $247.9 \pm 33.9 \mathrm{~g}$ \\
\hline ARMEN06-06 (Ae. triuncialis) & $185 \pm 27$ & $1.47 \pm 0.22 \mathrm{ab}$ & $67.7 \pm 4.0^{\text {defgh }}$ & $560.8 \pm 33.0^{\mathrm{i}}$ \\
\hline SVKBUR05-13 (Ae. cylindrica) & $343 \pm 78$ & $2.44 \pm 0.55^{\mathrm{bcd}}$ & $39.6 \pm 3.7^{b c}$ & $177.5 \pm 6.7^{\mathrm{f}}$ \\
\hline SVKHUN06-48 (Ae. cylindrica) & $414 \pm 89$ & $3.01 \pm 0.64^{\mathrm{cd}}$ & $62.1 \pm 3.4^{\text {cdefg }}$ & $230.2 \pm 12.7^{g}$ \\
\hline Average-Aegilops & 296 & 1.81 & 46.35 & 258.1 \\
\hline
\end{tabular}

\# Average values \pm SE; different letters indicate statistically significant differences as indicated by Duncan's test at $p<0.05$.

Table 3. Correlation matrix of analyzed leaf, growth, and water loss traits in wheat and Aegilops genotypes \#\#.

\begin{tabular}{|c|c|c|c|c|c|c|c|c|}
\hline & $\begin{array}{c}\text { Cuticular } \\
\text { Transpiration }\end{array}$ & $\begin{array}{l}\text { Dry Mass } \\
\text { Per Plant }\end{array}$ & $\begin{array}{c}\text { Dry Mass } \\
\text { Per Leaf } \\
\text { Area }\end{array}$ & $\begin{array}{c}\text { Plant } \\
\text { Leaf Area }\end{array}$ & $\begin{array}{l}\text { Leaf Area } \\
\text { Index }\end{array}$ & $\begin{array}{c}\text { Flag Leaf } \\
\text { Area }\end{array}$ & $\begin{array}{c}\text { Water Loss } \\
\text { by CT } \\
\text { Per } \mathrm{m}^{2}\end{array}$ & $\begin{array}{c}\text { Water Loss } \\
\text { by CT } \\
\text { Per DM }\end{array}$ \\
\hline Cuticular transpiration & - & -0.55 * & -0.23 & $-0.65 *$ & $-0.65 *$ & $-0.63 *$ & -0.34 & $0.79 *$ \\
\hline Dry mass per plant & $-0.55 *$ & - & 0.41 & $0.72 *$ & $0.72 *$ & $0.82 *$ & $0.70 *$ & $-0.65 *$ \\
\hline Dry mass per leaf area & -0.23 & 0.41 & - & 0.19 & 0.19 & 0.33 & 0.21 & -0.34 \\
\hline Plant leaf area & $-0.65 *$ & $0.72 *$ & 0.19 & - & $0.99 *$ & $0.75 *$ & $0.87 *$ & $-0.42 *$ \\
\hline Leaf area index & $-0.65 *$ & $0.72 *$ & 0.19 & $0.99 *$ & - & $0.75 *$ & 0.87 * & -0.42 * \\
\hline Flag leaf area & $-0.63 *$ & 0.82 * & 0.33 & 0.75 * & $0.75 *$ & - & $0.65 *$ & $-0.60 *$ \\
\hline Water loss by CT per $\mathrm{m}^{2}$ & -0.34 & 0.70 * & 0.21 & $0.87 *$ & $0.87^{*}$ & $0.65 *$ & - & -0.16 \\
\hline Water loss by CT per DM & $0.79 *$ & $-0.65 *$ & -0.34 & $-0.42 *$ & $-0.42 *$ & $-0.60 *$ & -0.16 & - \\
\hline
\end{tabular}

\#\# Pearson's correlation indices; asterisks indicate statistically significant correlations at $p<0.05$.

We found a significant inverse correlation between cuticular transpiration and flag leaf area, indicating that nonproductive water loss is higher in smaller leaves than in larger leaves. However, this correlation was not very strong and was mainly associated with differences between Aegilops and wheat. The relationship between dry mass per leaf area and cuticular transpiration was insignificant, indicating no relationship between leaf thickness and cuticular transpiration. The correlation between cuticular transpiration and water loss by CT per soil area unit (correlation index equal to -0.34 ) indicates that 
total water loss by $\mathrm{CT}$ was more influenced by plant leaf area (correlation index equal to 0.87 ). However, when recalculated to dry mass, the trend was inverse, and cuticular transpiration was very relevant. This confirms that cuticular transpiration is a component relevant to water use efficiency. Our results also confirmed that the leaf area and LMA are independent traits with a very weak correlation. A significant negative correlation between the dry mass per plant and water loss by CT may be interesting from evolutionary and breeding perspectives, indicating that long-term selection led to improvements in cuticular transpiration to eliminate nonproductive water loss.

We also applied the hierarchical cluster analysis to visualize the similarity between the genotypes. The analysis based on the parameters related to cuticular transpiration (Figure 1a) shows a separation of the wheat and Aegilops genotypes; however, there were exemptions, such as ITASIC05-01, which was involved in a group represented by the majority of wheat genotypes. It well documents that the study of germplasm may provide individual accessions with more favorable traits. On the other hand, the analysis based on the growth and leaf traits (Figure 1b) confirmed a grouping of wheat and Aegilops.
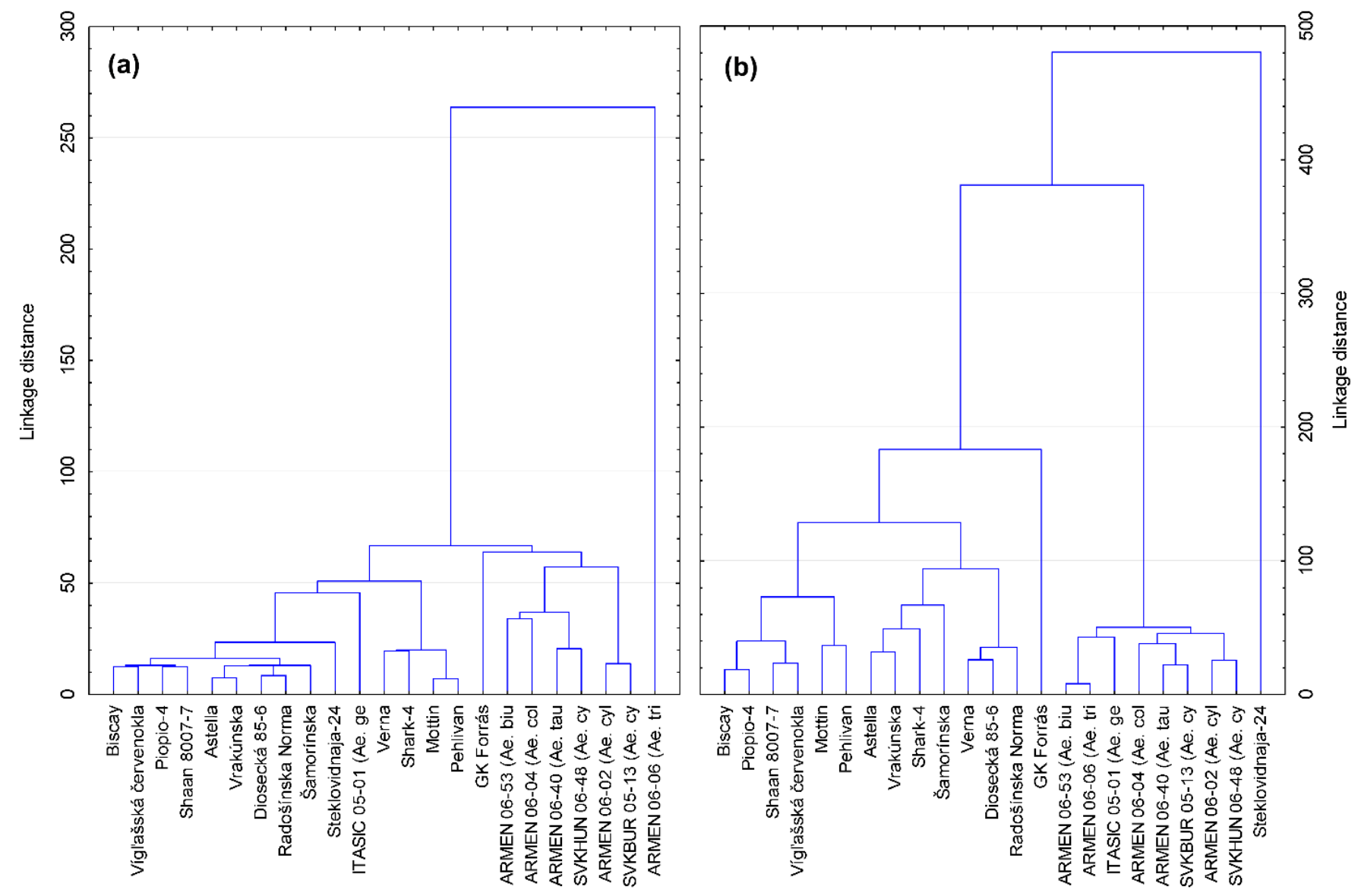

Figure 1. Dendrogram of Triticum and Aegilops genotypes obtained after applying hierarchical cluster analysis to the parameters related to cuticular transpiration (a) or leaf and growth parameters (b) using Euclidean coefficient and Ward's method.

\section{Discussion}

The plant leaf epidermis, especially the cuticle, acts as an effective protective barrier against uncontrolled water loss [36]. Water diffusion across the cuticle determines the rate and extent of water loss from aboveground primary plant organs [9]. In our results, it was possible to observe a visible difference in cuticular transpiration between individual genotypes but especially among the groups. The group of modern genotypes was characterized by three genotypes with generally the lowest values of nonproductive transpiration. This fact was demonstrably related to the leaf area. In a study by Carignato et al. [15], the 
behavior pattern of cuticular transpiration did not differ significantly based on leaf area in terms of differentiation among clones. The reduction in cuticular transpiration mentioned above may be due to increased accumulation of cuticular wax on the leaf surface because the wax layer is a fundamental water transport-limiting barrier of the cuticle, especially when the stomata are fully closed under stress conditions [37].

Wheat from the modern and landrace genotype groups had similar CT values. An explanation for this could be that genotypes from these groups are commonly grown species for food production, which are often cultivated without an irrigation system. Therefore, under conditions where water availability is limited, they need to have lower cuticular permeability than those living in humid conditions [9]. Aegilops species significantly differed from the average. The genotypes with the highest cuticular transpiration value were approximately $120 \%$ above the average of the analyzed genotypes. Similar differences among plants were found by Carignato et al. [15], where the plant with the highest cuticular transpiration value for the study period presented a CT that was $61 \%$ above the average of the nine others. This suggests that these genotypes in gravimetric measurements had a less efficient water saving strategy [38] than the other tested plants and thus lower drought resistance because wheat genotypes with lower cuticular transpiration adapted and performed better under water stress conditions [39]. It would logically follow that the lower the water loss by nonproductive transpiration, the more water the plant retains. Our study did not confirm a relationship of cuticular transpiration to water loss per $\mathrm{m}^{2}$ of leaf surface, which is consistent with the study of Burghardt and Riederer [40], who reported that cuticular transpiration was not affected by a reduction in leaf water content. According to Petcu et al. [10], water loss by cuticular transpiration shows a very significant effect of the genotype.

Leaf dry mass per unit area (LMA), which is the ratio between the leaf dry mass and the leaf area [41-43], is a critical trait that is closely associated with plant growth rates, reproductive strategies, and lifespan [44,45]. Despite being a morphological trait, LMA is highly correlated with leaf processes such as maximum photosynthesis [44,46-48], whole-plant activities such as the species' potential growth rate [49-52], and ecosystem processes such as decomposition rate [53-55]. It can be assumed that this is why the results of this work did not show the dependence of LMA on cuticular transpiration or on any of the measured parameters. According to Poorter et al. [41], the LMA values among terrestrial species in the field generally range from 30 to $330 \mathrm{~g} \mathrm{~m}^{-2}$. In our study, these values ranged from 32 to $52 \mathrm{~g} \mathrm{~m}^{-2}$, which are typical values for wheat. Higher values of LMA were evident in the first group of genotypes (modern), which, according to de la Riva [43], contributes to a long leaf life span, nutrient retention, and protection from desiccation.

In contrast, the lower values of LMA in the group of landraces and Aegilops potentially confer an advantage in resource-uptake efficiency by increasing the absorption surface per unit of tissue biomass [44,49]. Generally, in wheat, the mass of very fine and thin leaves is approximately $30 \mathrm{~g}$, while for larger, fleshier leaves, it is approximately $60 \mathrm{~g}$. Other studies have also found that variations in LMA depend on variations in the vasculature and sclerenchyma [43]. This suggests that wheat from the group of modern genotypes have thicker leaves suitable for greater adaptation to dry climates than the tested Aegilops. Our previous results confirmed a link between leaf thickness, respiration rate, and leaf photosynthesis [29]. Different environmental conditions may impose different selective pressures on plants, driving traits to a certain degree of divergence [56]. The tested plants in our experiment grew under the same conditions, but nevertheless, they differed in growth significantly. From this, we can deduce that differences in physiological traits such as dry mass per plant can be explained by their geographical origin and thus that these traits result from the pressure of natural selection exerted by the climatic constraints of the region of origin [27]. This would be in line with our findings, which is especially evident in the Aegilops group. 
Visible differences between plants were observed in all monitored leaf parameters. Enormous differences were evident within the groups, especially in the flag leaf area in the Aegilops group, which corresponds to the findings of Mcneal and Berg [57] that flag leaf areas were significantly different. Hasanuzzaman et al. [58] reported that cuticular transpiration was higher in old leaves than in young flag leaves. Young leaves tended to have less cuticular transpiration. This study found that the lowest values of cuticular transpiration were observed in the group of modern genotypes with the highest values of flag leaf areas. According to the LAI and PLA values, the densest stands were formed by the group of modern genotypes of wheat. The results also showed an inversely proportional relationship between the values of these parameters and cuticular transpiration. Thus, it is worth studying the relationship between cuticular transpiration and leaf permeability more in depth, paying attention to cuticle thickness, waxes, and trichomes, which could result in stable selection criteria [59,60].

The quantity of water lost through the cuticle is generally up to 10-20 times lower than the water loss through stomata. Nevertheless, when the stomata are closed, it represents the main method of water loss [10]. The highest average values of water loss per $\mathrm{m}^{2}$ were shown by modern wheat genotypes, given by a high LAI. Interestingly, two opposing peaks in water losses were recorded in Aegilops genotypes. Logically, the water loss per $\mathrm{m}^{2}$ was the lowest because these species had the smallest leaves in terms of area and weight. Differences were also found in wheat. The worst wheat genotype transpired through the cuticle almost three times more water per ground area than the best wheat genotype, which shows how much favorable cuticular transpiration can contribute to the efficiency of water use.

In addition, our results clearly indicated that water loss by cuticular transpiration per $g$ dry mass was correlated with dry mass per plant. This means that the smaller the plant, the more water is lost. Leaf surface properties, structure, the size and shape of the leaf cuticle, mesophyll cells, and air space will also affect water loss [61]. From ecological and evolutionary perspectives, cuticular transpiration is not very relevant for Aegilops with a low leaf area compared to wheat with a robust leaf apparatus. This explains why the selection of wheat led to higher resistance of the cuticle to water loss.

Aegilops is an important donor of genes related mostly to resistance to biotics but potentially also to abiotic stress factors. It is expected that more Aegilops will be used in breeding $[25,27,28]$, and multiple accessions of Aegilops species will be collected and stored in gene banks. However, crosses with Aegilops may lead to introgression of undesirable genes, including those associated with the permeability of the leaf cuticle. Although the values found in our study in wild species were significantly higher than those in the best modern wheat species, there was sufficient variability in this trait, and the genotypes with cuticular transpiration below the average could be identified. We did not find any link between cuticular transpiration and common leaf traits; hence, cuticular transpiration cannot be estimated without direct measurements. Therefore, it would be appropriate to extend the spectrum of traits analyzed in the phenotyping of genetic resources by analyzing cuticular transpiration. Alternatively, a focus on developing efficient molecular markers associated with low cuticular transpiration may represent a significant asset for breeding programs aimed at crop drought tolerance and water use efficiency.

The methods used in this study were efficient but still can be improved to provide even more precise information on cuticular transpiration of crop plants. In the next steps, the improvements of technical approaches of realizing experiments can be focused on developing systems to eliminate a boundary layer caused by placing the leaves on filter paper, which contributed to the diffusive resistance. Moreover, the experiments analyzing the heterogeneity of cuticular transpiration in different leaf positions can be beneficial, especially for using the data to create specific models. Moreover, there is still an open question related to the presence of aperture of the stomata in the darkness that may contribute to the value of cuticular transpiration [62]. Our results confirm that long-term exposition of leaves to darkness is insufficient to eliminate the stomatal transpiration 
completely (the values at the beginning of the procedure), but next dehydration associated with loss of turgor led to a significant decrease and stabilization of the transpiration rate. Thus, we can assume that the stomatal transpiration was minimized, and the water loss represents the cuticular transpiration. Nevertheless, the advanced studies combining the precise analytical with the fast screening methods in a sufficiently large collection of genotypes may bring important information on the potential and the limits of the proposed technical approach.

\section{Conclusions}

The analyses of samples obtained in a gene bank collection of modern wheat varieties, landraces, and the genotypes of Aegilops identified significant variability in leaf and growth traits, including leaf cuticular transpiration. The results indicated higher cuticular transpiration in Aegilops, but due to their much smaller leaf area, overall water loss of the canopy by nonstomatal transpiration was lower in wild wheat than in wheat genotypes with a robust leaf apparatus, in which resistance against unregulated water loss is crucial. This property was probably strengthened during the long-term selection of wheat, as suggested by comparing different groups of genotypes. The correlation analyses did not identify clear relationships between the common leaf traits and cuticular transpiration, suggesting the need for separate cuticular transpiration analyses as a part of crop phenotyping programs. It may help identify suitable candidates for breeding toward improved water use efficiency and drought tolerance and increase the efficiency of exploiting rich collections of genetic resources concentrated in gene banks.

Supplementary Materials: The following are available online at https:/ /www.mdpi.com/2073-439 5/11/3/522/s1, Figure S1: An example of the data observed by the gravimetric analysis within the analysis of cuticular transpiration in wheat and Aegilops leaves.

Author Contributions: Conceptualization, M.B. and M.Ž.; methodology, M.Ž.; validation, M.B., P.H. formal analysis, K.G. and M.Ž.; investigation, K.G. and M.Ž.; resources, M.B., and P.H.; data curation, K.G.; writing—original draft preparation, K.G. and M.Ž.; writing—review and editing, M.B., P.H. and M.Ž.; supervision, M.Ž. and M.B.; project administration, M.Ž. and M.B.; funding acquisition, M.B. All authors have read and agreed to the published version of the manuscript.

Funding: This work was supported by the Slovak Research and Development Agency project APVV-18-465. This work was also supported by the project OPVaI-VA/DP/2018/No. 313011T813.

Institutional Review Board Statement: Not applicable.

Informed Consent Statement: Not applicable.

Data Availability Statement: Data sharing not applicable.

Conflicts of Interest: The authors declare no conflict of interest.

\section{References}

1. Riederer, M.; Schreiber, L. Protecting against water loss: Analysis of the barrier properties of plant cuticles. J. Exp. Bot. 2001, 52, 2023-2032. [CrossRef] [PubMed]

2. Leide, J.; Hildebrandt, U.; Vogg, G.; Riederer, M. The positional sterile (ps) mutation affects cuticular transpiration and wax biosynthesis of tomato fruits. J. Plant Physiol. 2011, 168, 871-877. [CrossRef]

3. Schönherr, J. Resistance of plant surfaces to water loss: Transport properties of cutin, suberin and associated lipids. In Physiological Plant Ecology II. Encyclopedia of Plant Physiology (New Series); Lange, O.L., Nobel, P.S., Osmond, C.B., Ziegler, H., Eds.; Springer: Berlin/Heidelberg, Germany, 1982; Volume 12B, pp. 153-179.

4. Goodwin, S.M.; Jenks, M.A. Plant cuticle function as a barrier to water loss. In Plant Abiotic Stress; Jenks, M., Hasegawa, P., Eds.; Blackwell Scientific Publishers: Oxford, UK, 2005; pp. 14-36.

5. Kosma, D.K.; Jenks, M.A. Eco-physiological and molecular-genetic determinants of plant cuticle function in drought and salt stress tolerance. In Advances in Molecular Breeding towards Drought and Salt Tolerant Crops; Jenks, M.A., Hasegawa, P.M., Jain, S.M., Eds.; Springer: Dortrecht, The Netherlands, 2007; pp. 91-120.

6. Huihui, B.; Kovalchuk, N.; Langridge, P.; Tricker, P.; Lopato, S.; Borisjuk, N. The impact of drought on wheat leaf cuticle properties. BMC Plant Biol. 2017, 17, 2-13. [CrossRef] 
7. Holmgren, P.; Jarvis, P.G.; Jarvis, M.S. Resistances to Carbon Dioxide and Water Vapor Transfer in Leaves of Different Plant Species. Physiol. Plant. 1965, 18,557-573. [CrossRef]

8. Zhang, Y.; Chen, X.; Du, Z.; Zhang, W.; Devkota, A.R.; Chen, Z.; Chen, C.; Sun, W.; Chen, M. A Proposed Method for Simultaneous Measurement of Cuticular Transpiration from Different Leaf Surfaces in Camellia sinensis. Front. Plant Sci. 2020, 11, 420. [CrossRef] [PubMed]

9. Schuster, A.-C.; Burghardt, M.; Riederer, M. The ecophysiology of leaf cuticular transpiration: Are cuticular water permeabilities adapted to ecological conditions? J. Exp. Bot. 2017, 68, 5271-5279. [CrossRef]

10. Petcu, E.; Maria, S.; Cirstea, V.E. The effect of water stress on cuticular transpiration and its association with alfalfa yield. Rom. Agric. Res. 2009, 26, 53-56.

11. Jetter, R.; Schäffer, S.; Riederer, M. Leaf cuticular waxes are arranged in chemically and mechanically distinct layers: Evidence from Prunus laurocerasus L. Plant Cell Environ. 2000, 23, 619-628. [CrossRef]

12. Canny, M.J.; Huang, C.X. Leaf water content and palisade cell size. New Phytol. 2006, 170, 75-85. [CrossRef]

13. Ali, I.; Abbas, S.Q.; Hameed, M.; Naz, N.; Zafar, S.; Kanwal, S. Leaf anatomical adaptations in some exotic species of Eucalyptus l'hér. (Myrtaceae). Pak. J. Bot. 2009, 41, 2717-2727.

14. Oteros, J.; García-Mozo, H.; Vázquez, L.; Mestre, A.; Dominguezvilches, E.; Galan, C. Modelling olive phenological response to weather and topography. Agric. Ecosyst. Environ. 2013, 179, 62-68. [CrossRef]

15. Carignato, A.; Vázquez-Piqué, J.; Tapias, R.; Ruiz, F.; Fernández, M. Variability and Plasticity in Cuticular Transpiration and Leaf Permeability Allow Differentiation of Eucalyptus Clones at an Early Age. Forest 2020, 11, 9. [CrossRef]

16. Kramer, P.J. Drought, stress and the origin of adaptation. In Adaptation of Plants to Water and High Temperature Stress; Turner, N., Kramer, P.J., Eds.; Academic Press: San Diego, CA, USA, 1980; pp. 7-20.

17. Boyer, J.S. Plant Productivity and Environment. Science 1982, 218, 443-448. [CrossRef] [PubMed]

18. David, M. Osmotic adjustment capacity and cuticular transpiration in several wheat cultivars cultivated in Algeria. Rom. Agric. Res. 2009, 26, 29-33.

19. Dewey, D.R. The genomic system of classification as a guide to intergeneric hybridization with the perennial Triticeae. In Gene Manipulation in Plant Improvement; Gustafson, J.P., Ed.; Columbia University Press: New York, NY, USA, $1984 ;$ pp. $209-279$.

20. Chen, N.; Chen, W.-J.; Yan, H.; Wang, Y.; Kang, H.-Y.; Zhang, H.-Q.; Zhou, Y.-H.; Sun, G.-L.; Sha, L.-N.; Fan, X. Evolutionary patterns of plastome uncover diploid-polyploid maternal relationships in Triticeae. Mol. Phylogenet. Evol. 2020, $149,106838$. [CrossRef]

21. Nazari, M.; Moosavi, S.S.; Maleki, M. Morpho-physiological and proteomic responses of Aegilops tauschii to imposed moisture stress. Plant Physiol. Biochem. 2018, 132, 445-452. [CrossRef]

22. Asseng, S.; Guarin, J.R.; Raman, M.; Monje, O.; Kiss, G.; Despommier, D.D.; Meggers, F.M.; Gauthier, P.P.G. Wheat yield potential in controlled-environment vertical farms. Proc. Natl. Acad. Sci. USA 2020, 117, 19131-19135. [CrossRef] [PubMed]

23. Tilman, D.; Balzer, C.; Hill, J.; Befort, B.L. Global food demand and the sustainable intensification of agriculture. Proc. Natl. Acad. Sci. USA 2011, 108, 20260-20264. [CrossRef]

24. Gloser, J.; Barták, M.; Gloser, V. Changes in photosynthetic parameters of evolutionary different species of triticum and Aegilops grown at high and low nitrogen availability. In Photosynthesis: Mechanisms and Effects; Garab, G., Ed.; Kluwer Academic Publishers: Dortrecht, The Nederlands, 1998; Volume V, pp. 3789-3792.

25. Van Slageren, M.W. Wild Wheats: A Monograph of Aegilops L. and Amblyopyrum (Jaub and Spach) Eig (Poaceae); Wageningen Agricultural University Papers: Aleppo, Syria, 1994; pp. 1-512.

26. Molnár, I.; Gáspár, L.; Sárvári, E.; Dulai, S. Physiological and morphological responses to water stress in Aegilops biuncialis and Triticum aestivum genotypes with differing tolerance to drought. Funct. Plant Biol. 2004, 31, 1149-1159. [CrossRef]

27. Zaharieva, M.; Gaulin, E.; Havaux, M.; Acevedo, E. Drought and heat responses in the wild wheat relative Aegilops geniculata Roth: Potential interest for wheat improvement. Crop Sci. 2001, 41. [CrossRef]

28. Colmer, T.D.; Flowers, T.J.; Munns, R. Use of wild relatives to improve salt tolerance in wheat. J. Exp. Bot. 2006, 57, 1059-1078. [CrossRef] [PubMed]

29. Brestic, M.; Zivcak, M.; Hauptvogel, P.; Misheva, S.; Kocheva, K.; Yang, X.; Li, X.; Allakhverdiev, S.I. Wheat plant selection for high yields entailed improvement of leaf anatomical and biochemical traits including tolerance to nonoptimal temper-ature conditions. Photosynth. Res. 2018, 136, 245-255. [CrossRef] [PubMed]

30. Monneveux, P.; Zaharieva, M.; Rekika, D.; Royo, C. The utilization of Triticum and Aegilops species for the improvement of durum wheat. In Durum Wheat Improvement in the Mediterranean Region: New Challenges; Royo, C., Nachit, M., Di Fonzo, N., Araus, J.L., Eds.; CIHEAM: Zaragoza, Spain, 2000; pp. 71-81.

31. Leśniowska-Nowak, J.; Okoń, S.; Wieremczuk, A. Molecular diversity analysis of genotypes from four Aegilops species based on retrotransposon-microsatellite amplified polymorphism (REMAP) markers. Cereal Res. Commun. 2020, 49, 37-44. [CrossRef]

32. Bultynck, L.; Fiorani, F.; Van Volkenburgh, E.; Lambers, H. Epidermal cell division and cell elongation in two Aegilops species with contrasting leaf elongation rates. Funct. Plant Biol. 2003, 30, 425-432. [CrossRef]

33. Brestic, M.; Zivcak, M.; Kunderlikova, K.; Allakhverdiev, S.I. High temperature specifically affects the photoprotective responses of chlorophyll b-deficient wheat mutant lines. Photosynth. Res. 2016, 130, 251-266. [CrossRef] [PubMed] 
34. Chovancek, E.; Zivcak, M.; Botyanszka, L.; Hauptvogel, P.; Yang, X.; Misheva, S.; Hussain, S.; Brestic, M. Transient Heat Waves May Affect the Photosynthetic Capacity of Susceptible Wheat Genotypes Due to Insufficient Photosystem I Photoprotection. Plants 2019, 8, 282. [CrossRef] [PubMed]

35. Chovancek, E.; Zivcak, M.; Brestic, M.; Hussain, S.; Allakhverdiev, S.I. The different patterns of post-heat stress responses in wheat genotypes: The role of the transthylakoid proton gradient in efficient recovery of leaf photosynthetic capacity. Photosynth Res. 2021, 1-15. [CrossRef]

36. Yul Yoo, C.; Pence, H.E.; Hasegawa, P.M.; Mickelbart, M.V. Regulation of Transpiration to Improve Crop Water Use. Crit. Rev. Plant Sci. 2009, 6, 410-431. [CrossRef]

37. Hasanuzzaman, M.; Shabala, L.; Zhou, M.; Brodribb, T.J.; Corkrey, R.; Shabala, S. Factors determining stomatal and non-stomatal (residual) transpiration and their contribution towards salinity tolerance in contrasting barley genotypes. Environ. Exp. Bot. 2018, 153, 10-20. [CrossRef]

38. Andivia, E.; Carevic, F.; Fernandez, M.; Alejano, R.; Vázquez-Piqué, J.; Tapias, R. Seasonal evolution of water status after outplanting of two provenances of Holm oak nursery seedlings. New For. 2012, 43, 815-824. [CrossRef]

39. David, M. Water loss from excised leaves in collection of Triticum aestivum and Triticum durum cultivars. Rom. Agric. Res. 2010, 27, 27-34.

40. Burghardt, M.; Riederer, M. Ecophysiological relevance of cuticular transpiration of deciduous and evergreen plants in relation to stomatal closure and leaf water potential. J. Exp. Bot. 2003, 54, 1941-1949. [CrossRef] [PubMed]

41. Poorter, H.; Niinemets, Ü.; Poorter, L.; Wright, I.J.; Villar, R. Causes and consequences of variation in leaf mass per area (LMA): A meta-analysis. New Phytol. 2009, 182, 565-588. [CrossRef] [PubMed]

42. Witkowski, E.T.F.; Lamont, B.B. Leaf specific mass confounds leaf density and thickness. Oecologia 1991, 88, 486-493. [CrossRef] [PubMed]

43. De La Riva, E.G.; Tosto, A.; Pérez-Ramos, I.M.; Navarro-Fernández, C.M.; Olmo, M.; Anten, N.P.R.; Marañón, T.; Villar, R. A plant economics spectrum in Mediterranean forests along environmental gradients: Is there coordination among leaf, stem and root traits? J. Veg. Sci. 2016, 27, 187-199. [CrossRef]

44. Wright, I.J.; Reich, P.B.; Westoby, M.; Ackerly, D.; Baruch, Z.; Bongers, F.; Cavender-Bares, J.; Chapin, T.; Cornelissen, J.H.C.; Diemer, M.; et al. The worldwide leaf economics spectrum. Nature 2004, 428, 821-827. [CrossRef]

45. Lin, S.; Niklas, K.J.; Wan, Y.; Hölscher, D.; Hui, C.; Ding, Y.; Shi, P. Leaf shape influences the scaling of leaf dry mass vs. area: A test case using bamboos. Ann. For. Sci. 2020, 77, 1-15. [CrossRef]

46. Oren, R.; Schulze, E.-D.; Matyssek, R.; Zimmermann, R. Estimating photosynthetic rate and annual carbon gain in conifers from specific leaf weight and leaf biomass. Oecologia 1986, 70, 178-193. [CrossRef]

47. Reich, P.B.; Walters, M.B.; Ellsworth, D.S. From tropics to tundra: Global convergence in plant functioning. Proc. Natl. Acad. Sci. USA 1997, 94, 13730-13734. [CrossRef]

48. Quero, J.L.; Villar, R.; Marañón, T.; Zamora, R. Interactions of drought and shade effects on seedlings of four Quercus species: Physiological and structural leaf responses. New Phytol. 2006, 170, 819-834. [CrossRef] [PubMed]

49. Reich, P.B.; Walters, M.B.; Ellsworth, D.S. Leaf Life-Span in Relation to Leaf, Plant, and Stand Characteristics among Diverse Ecosystems. Ecol. Monogr. 1992, 62, 365-392. [CrossRef]

50. Poorter, H.; Van der Werf, A. Is inherent variation in RGR determined by LAR at low irradiance and by NAR at high irradiance? A review of herbaceous species. In Inherent Variation in Plant Growth; Lambers, H., Poorter, H., Van Vuuren, M.M.I., Eds.; Backhuys Publishers: Leiden, The Netherland, 1998; pp. 309-336.

51. Antúnez, I.; Retamosa, E.C.; Villar, R. Relative growth rate in phylogenetically related deciduous and evergreen woody species. Oecologia 2001, 128, 172-180. [CrossRef] [PubMed]

52. Ruiz-Robleto, J.; Villar, R. Relative Growth Rate and Biomass Allocation in Ten Woody Species with Different Leaf Longevity Using Phylogenetic Independent Contrasts (PICs). Plant Biol. 2005, 7, 484-494. [CrossRef]

53. Lopez-Iglesias, B.; Olmo, M.; Gallardo, A.; Villar, R. Short-term effects of litter from 21 woody species on plant growth and root development. Plant Soil 2014, 381, 177-191. [CrossRef]

54. Cornelissen, J.H.C.; Thompson, K. Functional leaf attributes predict litter decomposition rate in herbaceous plants. New Phytol. 1997, 135, 109-114. [CrossRef]

55. Cornelissen, J.H.C.; Perez-Harguindeguy, N.; Diaz, S.; Grime, J.P.; Marzano, B.; Cabido, M.; Vendramini, F.; Cerabolini, B. Leaf structure and defence control litter decomposition rate across species and life forms in regional floras on two continents. New Phytol. 1999, 143, 191-200. [CrossRef]

56. Zhang, B.; Xiaozhen, L.; Jiang, J.; DeAngelis, D.L.; Fu, Z.; Zhang, J. Similarity of plant functional traits and aggregation pattern in a subtropical forest. Ecol. Evol. 2017, 7, 4086-4098. [CrossRef]

57. McNeal, F.H.; Berg, M.A. Flag leaf area in five spring wheat crosses and the relationship to grain yield. Euphytica 1977, 26, 739-744. [CrossRef]

58. Hasanuzzaman, M.; Davies, N.W.; Shabala, L.; Zhou, M.; Brodribb, T.J.; Shabala, S. Residual transpiration as a component of salinity stress tolerance mechanism: A case study for barley. BMC Plant Biol. 2017, 17, 1-12. [CrossRef]

59. Li, H.; Madden, J.L.; Potts, B.M. Variation in leaf waxes of the Tasmanian Eucalyptus species-I. Subgenus Symphyomyrtus. Biochem. Syst. Ecol. 1997, 25, 631-657. [CrossRef] 
60. Migacz, I.P.; Raeski, P.A.; Almeida, V.P.; Raman, V.; Nisgoski, S.; Muniz, G.I.B.; Farago, P.V.; Khan, I.A.; Budel, J.M. Comparative leaf morpho-anatomy of six species of Eucalyptus cultivated in Brazil. Rev. Bras. Farm. 2018, 28, 273-281. [CrossRef]

61. Berry, C.Z.; Emery, N.C.; Gotsch, S.G.; Goldsmith, G.R. Foliar water uptake: Processes, pathways, and integration into plant water budgets. Plant Cell Environ. 2018, 42, 410-423. [CrossRef] [PubMed]

62. Kerstiens, G. Diffusion of water vapour and gases across cuticles and through stomatal pores presumed closed. In Plant $\mathrm{Cu}$-ticles: An Integrated Functional Approach; BIOS Scientific: Oxford, UK, 1996; pp. 121-134. 